\title{
Learning from Other Sites
}

\section{Apprendre d'autres sites}

\author{
by LESLIE L. ROOS \\ Director, Population Health Research Data Repository \\ Manitoba Centre for Health Policy \\ Professor, Department of Community Health Services \\ Faculty of Medicine, University of Manitoba \\ Winnipeg, $M B$
}

\begin{abstract}
What should Canadian healthcare researchers pay attention to on the World Wide Web? What might be done to magnify the Canadian footprint on the Internet? This commentary discusses two very successful sites - OpenCourseWare from the Massachusetts Institute of Technology and the Epidemiology Supercourse from the University of Pittsburgh. The Mythbuster series (from the Canadian Health Services Research Foundation) and the Regional Training Centres have Web presences that might benefit from applying the techniques used by OpenCourseWare and the Supercourse. For a relatively small investment, Canadian efforts to improve dissemination and teaching in the health policy/health services research area might reach a larger national and international audience.
\end{abstract}

\section{Résumé}

Quels éléments du World Wide Web devraient retenir l'attention des chercheurs canadiens du domaine des soins de santé? Que peut-on faire pour rehausser la visibilité du Canada sur Internet? Ce commentaire traite de deux sites très populaires - 
OpenCourseWare du Massachusetts Institute of Technology et le Epidemiology Supercourse de l'Université de Pittsburgh. La série À bas les mythes (de la Fondation canadienne de la recherche sur les services de santé) et les Centres régionaux de formation ont une présence sur Internet qui pourrait bénéficier de l'application des techniques utilisées par OpenCourseWare et le Supercourse. Moyennant un investissement relativement modeste, les initiatives canadiennes visant à améliorer la diffusion et l'enseignement dans le domaine de la recherche sur les politiques et les services de santé pourraient atteindre un auditoire national et international plus vaste.

W here is Canada's healthcare research presence on the Web? What should it be? Some excellent material is available. At the same time, important approaches have been developed outside Canada. These efforts should challenge us to better highlight some aspects of Canadian teaching and research. I will state my bias up front: individuals and departments should provide as much of their teaching materials as possible without cost to the user. This will enhance their impact locally, nationally and internationally.

Two sites serve as a great source of ideas for Canadian work: the Massachusetts Institute of Technology's OpenCourseWare and the Epidemiology Supercourse (based at the University of Pittsburgh, with heavy international participation). MIT's innovative move in providing a large amount of material from each of its undergraduate and graduate courses has earned plaudits from many sources (including the Havana Agricultural University!). Intellectual property issues (professors' "ownership" of their course materials) appear to have been resolved. A standard format has been imposed so that reading lists, course outlines, lecture PowerPoint presentations and so forth are freely available for each course. Special materials (such as videos of demonstrations) are included where appropriate. Although MIT's large-scale efforts were aided by substantial foundation funding, Canadian departments in any field could follow its example. How much do most of us gain by safeguarding our course material through password-protected university accounts? Having a wider intellectual impact through dissemination of this material is a real advantage.

The Epidemiology Supercourse serves as a very successful, low-budget model for dissemination. According to its website, the Supercourse "is designed to provide an overview on epidemiology and the Internet for medical and health related students around the world." Following the work of Ron LaPorte and many others, professors have volunteered their best lectures to this effort to facilitate the teaching of epidemiology, public health, health services research and population health. Approximately 2,500 lectures in PowerPoint format (as well as other teaching materials using different formats) have been disseminated on 45 servers around the world. My experi- 
ence with developing several lectures for the Supercourse has convinced me that they help draw interested students to the website of the Manitoba Centre for Health Policy. Schools of public health based on the material presented in the Epidemiology Supercourse have now been proposed.

Canada has made some interesting efforts - but they could and should be having a larger impact. The Canadian Health Services Research Foundation (CHSRF) has developed its valuable series, Mythbusters \& EvidenceBoosts, to summarize evidence about important Canadian policy issues. This material is available on the CHSRF website and has been distributed using more traditional methods (mailouts, academic journals). It would be easy to reorganize the material in Mythbusters \& EvidenceBoosts as lectures in the Epidemiology Supercourse. Perhaps the lectures could be combined to provide a course on policy issues in Canadian healthcare. Although many Canadian academics are familiar with this material, I imagine few professors outside Canada are.

The issue of effective dissemination is highlighted by perusal of websites associated with Canada's Regional Training Centres (funded by the CHSRF, the Canadian Institutes for Health Research and other organizations). How many of us teaching in this field know anything about centres other than the ones with which we are affiliated? Have we been able to draw on others' material for our own teaching and training? Several centres note an interest in distance education, but no materials are posted. What might give them a larger national or international footprint? No doubt some great lectures should be dual-listed on Regional sites and with the Supercourse. Are there some existing Supercourse lectures (by Canadians or others) that should be noted back at the Regional sites? Canadian material would fill niches in the Supercourse dealing with health policy, health services research and population health that are currently underserved. Another approach might be a centralized posting of relevant course outlines being used at one or more universities; MIT's OpenCourseWare provides a template that can easily be followed. Even more modestly, an inventory of Canadian teaching material, available free of charge on the Internet, could be compiled and posted at the CHSRF site (preferably with links to the material itself).

Adoption of any (or all!) of these suggestions would highlight Canadian efforts and prove helpful for teachers and students.

\section{REFERENCES}

Canadian Health Services Research Foundation (CHSRF). 2006 (February 16). CHSRF/CIHR Regional Training Centres. Retrieved February 16, 2006. <http://www.chsrf.ca/cadre/regional_ training_centres_e.php>

Canadian Health Services Research Foundation (CHSRF). 2006 (February 16). Mythbusters \& EvidenceBoosts. Retrieved February 16, 2006. <http://www.chsrf.ca/mythbusters/index_e.php> 
Massachusetts Institute of Technology. 2005. OpenCourseWare. Retrieved February 16, 2006. <http://ocw.mit.edu/index.html>

University of Pittsburgh. 2006 (February 16). Supercourse: Epidemiology, the Internet and Global Health. Retrieved February 16, 2006. <http://www.pitt.edu/ super1>

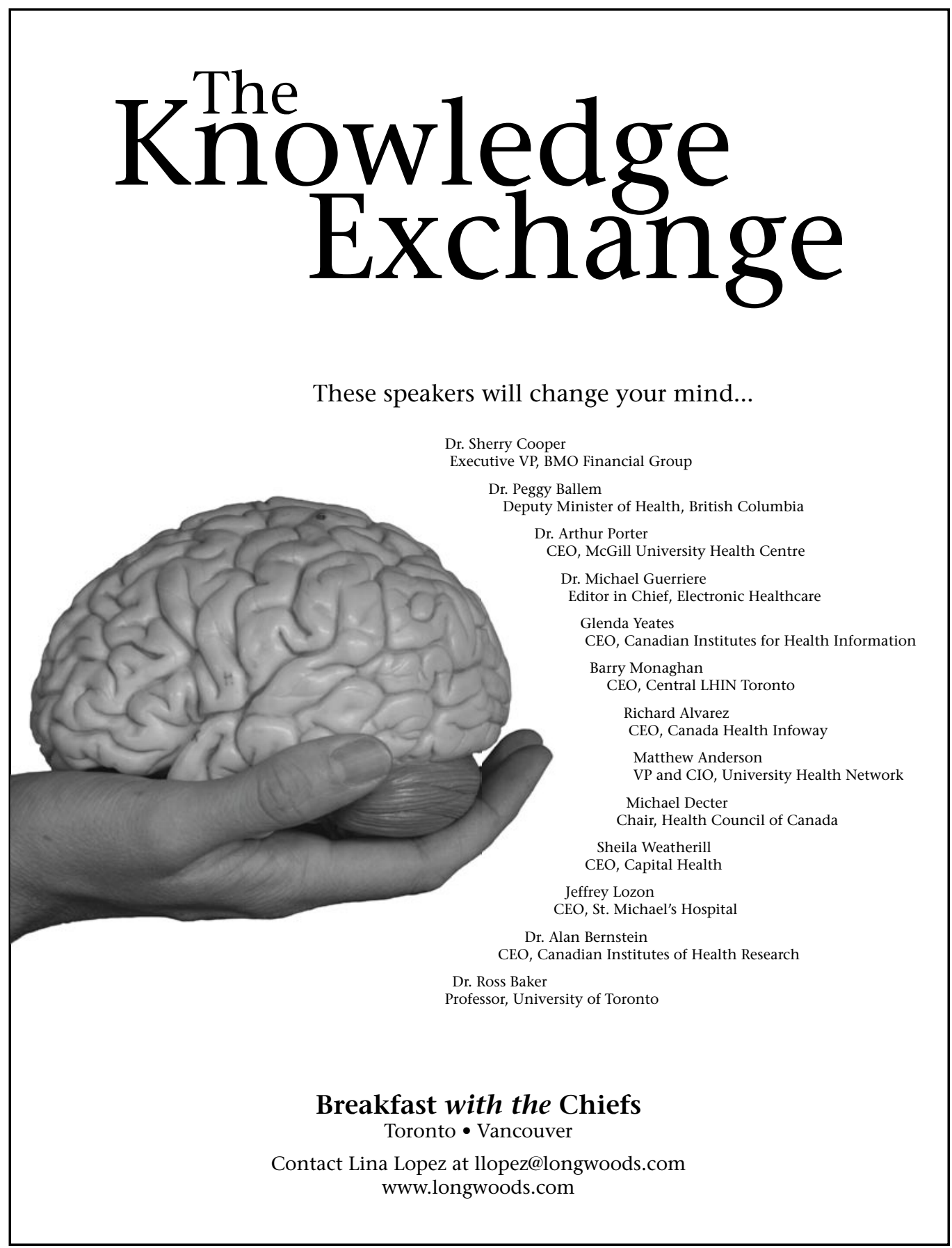

